Teosofia: Indonesian Journal of Islamic Mysticism, Vol. 10, No. 2, 2021, pp. 267-281

e-ISSN: 2540-8186; p-ISSN: 2302-8017

DOI: $10.21580 /$ tos.v10i2.9479

\title{
SUFISM AND KENOSIS: The Basis of One's Resilience as a Zoom Politicon
}

\author{
Martina Novalina \\ STT Ekumene Jakarta \\ Corresponding Author: martina@sttekumene.ac.id \\ Erastus Sabdono \\ STT Ekumene Jakarta \\ erastus.sabdono@sttekumene.ac.id \\ Indria Samego \\ STT Ekumene Jakarta \\ indriasamego32@gmail.com
}

Article History: Received: 3 August 2021; Accepted: 23 December 2021; Published: 31 December 2021

\begin{abstract}
:
The COVID-19 pandemic has brought humans into a new civilization, where Zoom meeting is no longer just an application but a changing pattern of human interaction with each other. This change, of course, requires adaptation, and not a few end up having problems due to Work From Home. Zoom applications risked two times of experiencing fatigue in students and four times of experiencing stress and also having issues in disruption of social functioning. This article aims to provide a solution to a person's resilience as a social being in the zoom era (zoom politicon) by applying Sufism and kenosis values. The approach used is library research. Through this study, we can see that some of the values in Sufism and kenosis have become the basis for a person to survive all challenges in life, especially amid fatigue doing activity online. These current values also protect a person from being caught up in a sin that eventually perishes. Human values as a part of zoom politicon must still be put forward to reflect one's spiritual journey to God.
\end{abstract}

Keywords: Kenosis; Resilience; Sufism; Zoom politicon.

\section{A. Introduction}

7 he Covid 19 pandemic brought humans into a new civilization, where every activity has commonly done face-to-face shifted into activities in the network.

1 When interacting with others, those who are used to mobile should replace it with online meetings, which are generally done through virtual applications. One of 
them is the Zoom meeting app. In 2020, the zoom meeting application occupied the first position as the most frequently used online meeting and video conference application. ${ }^{1}$

Over time, Zoom can no longer be said to be just a mere meeting app. Additional feat ures such as games, beauty filters, galley views, real-time language translation, and more make virtual meetings more engaging, less rigid, and provide new experiences in the app. ${ }^{2}$ And this is well utilized by some communities in communicating and socializing. ${ }^{3}$ Zoom meetings become a container of changing patterns of human interaction with others, which in other terms, I will refer to it as Zoom Politicon. The word Zoom Politicon is derived from the understanding of Zoon Politicon, a term for humans as social creatures who are drafted to interact with each other. ${ }^{4}$ This work from home (WFH) or study from home (SFH) condition makes Zoon Politicon turn into Zoom Politicon.

Changes experienced by the community in doing activities through virtual meetings certainly require adaptation. People end up experiencing problems due to WFH or SFH online, where they have to socialize (active) through a computer at all times. Some previous studies have said that the problem that often occurs during WFH or SFH is depression due to loneliness, fatigue, stress, insomnia, and others. ${ }^{5}$

1 INDOZONE.ID, "5 Aplikasi Meeting Online Dan Video Conference Jarak Jauh Terbaik," INDOZONE.ID, last modified 2020, https://www.indozone.id/tech/pQsoXr/5-aplikasi-meetingonline-dan-video-conference-jarak-jauh-terbaik/read-all, accessed October 13, 2021.

2 Mobilesyrup, "Zoom Akan Punya Penerjemah Bahasa 'Real Time," Tekno.Kompas, last modified 2021, accessed October 13, 2021, https://tekno.kompas.com/read/2021/07/04/08050037/zoom-akanpunya-penerjemah-bahasa-real-time-; CNET, "Zoom Punya Game Yang Bisa Dimainkan Sambil Meeting," Tekno.Kompas, last modified 2021, https://tekno.kompas.com/read/2021/07/25/15410067/zoom-punya-game-yang-bisa-dimainkansambil-meeting, accessed October 13, 2021.

3 Lori, "7 Games Seru Ini Bisa Dimainin Di Zoom Bareng Komunitas Gerejamu Loh!," Jawaban, last modified 2020, accessed 2021 , https://www.jawaban.com/read/article/id/2020/07/12/15/200710162308/7_games_seru_ini_bisa_dim ainin_di_zoom_bareng_komunitas_gerejamu_loh; Komunitas Traveler Kompasiana, "Begini Sejarah Zoom Komunitas Traveler Kompasiana Oleh Koteka Kompasiana - Kompasiana.Com," last modified February 23, 2021, https://video.kompasiana.com/kotekasiana/6034bbe301be08657d72b065/beginisejarah-zoom-komunitas-traveler-kompasiana?page=4, accessed October 13, 2021.

4 Nunuk Febriananingsih, “Jurnal RechtsVinding," Keterbukaan Informasi Publik Dalam Pemerintaan Terbuka Menuju Tata Pemerintahan Yang Baik 1, no. April (2012): 135-156, 2021, https://rechtsvinding.bphn.go.id/view/view_online.php?id=318, accessed October 13.

5 Dina Vebiola Saraswati Kuntardi, "Zoom Fatigue Dan Keberfungsian Sosial Di Kalangan Mahasiswa," Jurnal Publisitas 7, no. 2 (April 27, 2021): 72-79; Atikah Pustikasari and Lia Fitriyanti, "Stress Dan Zoom Fatigue Pada Mahasiswa Selama Pembelajaran Daring Di Masa Pandemi Covid19," Jurnal Ilmiah Kesehatan 13, no. 1 (March 30, 2021): 25-37, accessed October 12, 2021, http://journal.thamrin.ac.id/index.php/jikmht/article/view/467; Erik Peper et al., "Avoid Zoom Fatigue, Be Present and Learn," NeuroRegulation 8, no. 1 (March 29, 2021): 47-56; BEM Fakultas Pendidikan Psikologi Universitas Negeri Malang, "Zoom Fatigue, Apakah Berpengaruh Terhadap Kesehatan Mental?," [PSYCHOFACT Vol.1], last modified 2021, http://bem.fppsi.um.ac.id/index.php/2021/06/20/psychofact-vol-1-zoom-fatigue-apakah-berpengaruhterhadap-kesehatan-mental/, accessed October 12, 2021. 
Pustikasari found that learning media using zoom applications risked two times experiencing fatigue in students and four times the risk of experiencing stress. The solution to this problem is to modify the learning media with various applications that do not require high concentration by selecting appropriate designs and methods. ${ }^{6}$ This finding is supported by Kuntardi, who stated that fatigue due to excessive zoom use resulted in disruption of social functioning. The advice given to overcome this condition involves social workers conducting evaluations, assessments, and interventions to improve social functioning. ${ }^{7}$ Fossilen and Duffy also provide zooming users with practical solutions to fatigue. They tell them to provide other focus on the eyes, such as minimizing tabs or taking their eyes off the screen entirely for a few seconds occasionally, limiting the duration/time of learning, and using other alternative media. ${ }^{8}$

From some of the previous research above, we can see that several efforts have been made so that online activities can still run well without having to experience obstacles that can be fatal to a person's health, both physical and mental. However, I have not seen any solution given from the point of view of spirituality. We cannot deny that Indonesian society with a variety of plurality still often involves spiritual things in dealing with various problems in life. One of the things that the author wants to offer through the study of this article is how one can eventually face problems in online activities (specifically in using the Zoom application) by applying the values contained in Sufism and kenosis.

The method used in this study is a qualitative approach through literature studies, where researchers look for sources relevant to the issues and concepts of Sufism that exist in Islamic teachings and kenosis in Christian teachings. According to Zaluchu, theology, part of the social sciences family, is open to any methodology and approach to truth. Any methodology cannot contest the truth of faith, but the truth of knowledge born of induction and deduction can be positioned within a series of scientific methods. Therefore, the arguments and empirical findings in the truth of faith are in an abstract position. However, in the truth of science, arguments and empirical findings in religious research can always be measured, seen and observed, even sued. An essential point in the spiritual study is not the debate about methods but the subject matter as the starting

6 Atikah Pustikasari and Lia Fitriyanti, "Stress Dan Zoom Fatigue Pada Mahasiswa Selama Pembelajaran Daring Di Masa Pandemi Covid-19," Jurnal Ilmiah Kesehatan 13, no. 1 (March 30, 2021): 25-37, http://journal.thamrin.ac.id/index.php/jikmht/article/view/467, accessed October 12, 2021.

7 Kuntardi, Dina Vebiola Saraswati. 2021. "Zoom Fatigue Dan Keberfungsian Sosial Di Kalangan Mahasiswa." Jurnal Publisitas 7 (2). Lembaga Penelitian and Pengabdian Masyarakat (LPPM) STISIPOL Candradimuka Palembang: 72-79. doi:10.37858/publisitas.v7i2.47.

8 BEM Fakultas Pendidikan Psikologi Universitas Negeri Malang, "Zoom Fatigue, Apakah Berpengaruh Terhadap Kesehatan Mental?," [PSYCHOFACT Vol.1], last modified 2021, http://bem.fppsi.um.ac.id/index.php/2021/06/20/psychofact-vol-1-zoom-fatigue-apakah-berpengaruhterhadap-kesehatan-mental/, accessed October 12, 2021. 
point of the research problem and its contribution. ${ }^{9}$ In this article, researchers limit the subject matter to the similarities of Sufism and kenosis values. Researchers divide it into two parts; some are discussed in the Sufism section. The others are discussed in the kenosis section. Moreover, they both have a corresponding value. Therefore, amid significant differences in religious teachings, readers can see that these two religions can embrace each other in applying the values contained in both concepts. Through this study, it is also hoped that some of the values contained in Sufism and kenosis, such as self-emptying, emotional control, directing the view to eternity, giving up worldly desires, and having a holy life, can be the basis for a person to survive all challenges in life, especially amid the fatigue of online activities.

\section{B. Resilience}

Resilience is understood to refer to positive adaptation or the ability to maintain or regain mental health. However, some understand it as adapting and remaining steadfast under challenging situations. ${ }^{10}$ However, some understand it as adapting and remaining reliable in difficult situations. ${ }^{11}$ Resilience makes a person successfully adjust in dealing with unpleasant conditions and even intense pressure.

According to Reivich and Shatté, Resilience is built from seven different abilities, and hardly a single individual overall has that ability. That ability consists of (1) Emotion Regulation, (2) Impulse Control, (3) Optimism, (4) Empathy, (5) Analysis of Problem Causes, (6) Self-Efficacy, (7) Improvement of Positive Aspects. ${ }^{12}$

Resilience is a psychological force in which a person can survive various difficulties. A person's resilience can bring them back from a difficult life situation. Resilience is a tremendous positive psychology capacity. Life is going to get negative and gruesome experiences - resilient individuals are the ones that can survive and move forward. Earlier, people believed that resilience was a genetic trait. Some family bloodlines are stronger than others. Research has found that resilience is a multidimensional capacity. It has a connection with various constructs - not only biology. ${ }^{13}$

9 Sonny Eli Zaluchu, "Strategi Penelitian Kualitatif Dan Kuantitatif Di Dalam Penelitian Agama," Evangelikal: Jurnal Teologi Injili dan Pembinaan Warga Jemaat 4, no. 1 (January 31, 2020): 36, https://journal.sttsimpson.ac.id/index.php/EJTI/article/view/167.

10 Helen Herrman et al., "What Is Resilience?," Canadian Journal of Psychiatry(SAGE Publications Sage CA: Los Angeles, $\quad$ CA, 1 May 2011), https://journals.sagepub.com/doi/abs/10.1177/070674371105600504, accessed 14 October 2021.

11 Michelle D. Keye and Aileen M. Pidgeon, "Investigation of the Relationship between Resilience, Mindfulness, and Academic Self-Efficacy," Open Journal of Social Sciences 01, no. 06 (2013): 1-4, http://www.scirp.org/journal/doi.aspx?DOI=10.4236/jss.2013.16001.

12 A. Reivich, K \& Shatte, The Resilience Factor; 7 Essential Skill For Overcoming Life's Inevitable Obstacle. (New York: Broadway Books, 2002).

13 "The Connection Between Spirituality and Resilience • Spirit Restoration," https://www.spiritrestoration.org/life/connection-between-spirituality-resilience/, accessed 14 October 2021. 
There is a connection between Spirituality and Resilience. Both have similar effects on the people who practice them. Spiritual and Resilient People have shown many similar traits and abilities. These combine the experiences of both and present the fundamental connection between the two.

Spirituality and resilience have similar impacts on different people, such as (a) changes in Perception: Spirituality leads to a change in your worldview. You rise above the daily knick-knacks. You do not worry yourself over frugal things. There is more focus on things that truly matter. Resilience also leads to a positive shift in your perception. It brings forward your courageous self. When a situation is frightening, resilience forces you to adopt a more brave perception. (b) Stress Levels: Spirituality and Resilience reduce your stress levels. Researchers found that people who are either spiritual or resilient are less stressed through different stress scales interventions. It is because spirituality does not center on meaningless stressors of life. Resilience beats stress through positive emotions and courage. (c) Happy Living: Happiness is a thread connecting spirituality and resilience. Spirituality promotes cheerful and straightforward living. Resilience indirectly builds happiness. When a terrifying event is presented, resilience and spirituality use positive emotions to cope and fight. Happiness usually follows such interventions. (d) Self-Discovery: Spiritual Awakenings follow individuals through a journey of self-discovery. Many people turn into new personalities after a divine spiritual experience. They discover who they indeed are. Resilience also leads to self-discovery. Adversity brings down everyone. These moments of vulnerability force us to meet our authentic selves. We cannot mask a tragedy. Resilience uses our most vital traits to help us move forward. ${ }^{14}$

\section{Sufism}

Science and technology are so sophisticated and elaborated to almost all world regions in this complex modern life. At which point man must be troubled by the problem of life that is all materialistic. In modern times, the relationship between humans also tends to be "impersonal," no longer familiar with each other. A wave of contemporary society erodes traditional societies. This phenomenon makes humans lose their identity more and more. Such conditions also require humans to survive and control themselves and remain rigid in personality.

In this life, what is needed by man is nothing but tranquility, the tranquility of the soul or inner happiness. It does not depend much on external factors, such as economic, social status, and so on, but rather on the attitude of life and closeness to Allah SWT. Therefore, getting closer and asking Allah for help (isti'āna and istighātha) remains relevant and necessary to obtain a healthy and decent life: a balanced soul, a noble person, and a calm heart. This is where Sufism means: putting forward the values of religious

14 "The Connection Between Spirituality and Resilience Spirit Restoration," 
teachings, spirituality, and esoteric aspects that are bastions of personality to avoid the hustle and bustle of materialism and hedonism, especially in this challenging global life.

Sufism, often also referred to by mystical terms (but not Javanese mysticism) related to inner affairs (but not kebatinan), has an understanding as an attempt to approach the Khaliq that moves in the sphere of taste, esoteric, (dhaūq) and heart (qalb). The efforts of this approach that moves in the realm of the spirit require clarity and sincerity. Therefore, this inner clarity or compassion is often identified with Sufism (tașawwuf, Arabic), where the culprit is Sufi (al-mutas awwif). Among society in general, life is known as a life that releases the desires and interests of the world. ${ }^{15}$

The practice of Sufism is done by focusing carefully on the following activities. First, tazkiyat al-nafs, cleans the soul from great sins and minor sins and cleanse itself of various diseases of the heart and reprehensible qualities. Second, taqarrub ilā Allāh, draw nearest to Allah. Third, hudūr al-qalb ma'allāh feels the presence of Allah in the heart, both in prayer and outside the prayer. Thus, practicing Sufism means struggling to be close to Allah by practicing worship as exemplified by the Prophet (peace be upon him).

\section{Emotional Control}

WFH or SFH activity through Zoom can cause a person's emotions to become unstable. This can interfere with the performance of the activity itself and have a fatal impact on a person's psychological. A mental science expert states that patients who survive long enough have a firm bond with their emotions. They know what they're feeling and don't feel scared or depressed by strong emotional emotions-from themselves or others. Most importantly, this relationship with their feelings motivates and activates their lives. This relationship brings them closer to others, even if they feel pain and suffering. Emotions also explain and foster spiritual relationships that these patients say are essential for their healing. ${ }^{16}$

Humans who can control emotions well will achieve best because emotions are an extraordinary force if held for positive and constructive purposes, effectively and efficiently. Emotional control must be directed to attain God-given goals in life on this earth and benefit from a happy life in the hereafter. Many people live in helplessness because they cannot control their emotions. They vent their emotions at will without any meaningful, purposeful and positive control.

Sufis often exemplify the teachings of personal dignity (morality), such as teachings on $z u h u \bar{d}$, patience, generosity, forbidden to say dirty, hurt others, and social

15 H M Zainuddin, "Sufisme Di Era Global," UIN Maulana Malik Ibrahim Malang, 2015, https://www.uin-malang.ac.id/r/131101/sufisme-di-era-global.html, accessed October 10, 2021.

16 Jeanne Segal, Raising Your Emotional Intelligence, Terj. Ali Nilandari Mendayagunakan, Melejitkan Kepekaan Emosional; Cara Baru-Praktis Untuk Potensi Insting Dan Kekuatan Emosi Anda, Cet. I. (Bandung,: Kaifa, 2000). 
solidarity. The teachings of Sufism are part of the teachings of Islam that foster human morals (just as Islam is also revealed to build the morals of humankind) on this earth to achieve the happiness and perfection of life born and inwardly, world and hereafter. ${ }^{17}$

The essence of Islamic teachings is the formation of humans who have individual health and social holiness. In Islam, lust is classified into four: first, ammā ra that is the passion for anger. Second, lawwāma that has developed a desire to do good, and regret when making mistakes (QS. 75:2). Third, mutma'inna that is the holy, gentle, and calm soul whom He invited with great pleasure to Heaven (QS. 89:27). Fourth, mulhama that is always under the guidance and whispers of Allah. All his movements, behavior, and will are in the inspiration, guidance, and will of Allah (QS. 91:8). Thus, the ability of man to control his passions will make his soul mature, flourishing to fill the behavior of his life so that it will reflect the inner expression in his behavior. It can make him able to make the task of his caliphate on the face of the earth wisely and wisely to achieve success in this world and the hereafter. ${ }^{18}$

\section{Giving Up Worldly Desire (Asceticism)}

The practice of asceticism in Islam is the first step in the birth of zuhūdlife, where it means not feeling proud of the luxury of the world they already have and not feeling sad because they lose the luxury of themselves. ${ }^{19}$

$Z u h \bar{u} d$ life in Islam is an integral part of Sufi life because $z u h \bar{u} d$ has consequences of self-avoidance of the world in totality to worship Allah SWT. Still, zuhūd life in the moral context of Islam is interpreted as abandoning the heart's dependence on a property (material), although it does not mean antipathy towards it.

Human religiosity is manifested in various sides of human life. Religious activity occurs when a person performs ritual behavior (worship) and other activities encouraged by transcendent forces. Not only related to visible activities but includes invisible activities that happen in a person's heart.

However, zuhū $d$ does not belong solely to Sufis. In the Sufi tradition, zuhū $d$ is one of the spiritual stages (maqâm) that the Sufi candidate must pass to be as close to God as possible. More than that, zuhūd is an essential attitude for Muslims everywhere, especially in today's modern context. ${ }^{20}$

17 Moh. Gitosaroso, "Kecerdasan Emosi (Emotional Intelligence Dalam Tasawuf)," Jurnal Khatulistiwa $\begin{array}{lllllll}\text { - Journal Of Islamic } & \text { Studies 2, no. } 2 & \text { (2012): } & \text { 193, }\end{array}$ https://jurnaliainpontianak.or.id/index.php/khatulistiwa/article/view/206/165.

18 Moh. Gitosaroso, “Kecerdasan Emosi (Emotional Intelligence Dalam Tasawuf)," 193

19 Syaiful Hamali, “ASKETISME DALAM ISLAM PERSPEKTIF PSIKOLOGI AGAMA," Al-Adyan: Jurnal Studi Lintas Agama 10, no. 2 (2015): 202-215, http://ejournal.radenintan.ac.id/index.php/alAdyan/article/view/1429, accessed October 20, 2021.

20 H. Muhtar Solihin, “Memaknai Zuhud Kontekstual Di Masa Covid-19," UIN Sunan Gunung Djati Bandung, last modified 2020, https:/uinsgd.ac.id/memaknai-zuhud-kontekstual-di-masa-covid-19/, accessed October 20, 2021.

Teosofia: Indonesian Journal of Islamic Mysticism, Vol. 10, No. 2, 2021 
Zuhūd's behavior is not merely unwilling to own possessions and not think about worldly affairs, but zuhū $d$ in the true sense of a person who is not affected by controls and objects in devoting himself to Allah SWT. Thus, one may be "rich," but no matter how wealthy a person may be, they still live in a state of zuhüd, i.e., unaffected by the wealth in devoting themselves to God. They use wealth to draw near and worship Allah SWT. Zuhü $d$ people are always wary of the dangers arising from the inappropriate use of the property because holding wealth is like someone having embers in the palm of his hand that can burn himself. ${ }^{21}$

In the condition of WFH and SFH, selfishness, greed, and love of the world should be suppressed and replaced with a zuhūd attitude characterized by mutual sharing and mutual love. Refraining from looking for a spectacle that can satisfy the eyes and fantasizing amid fatigue using zoom is another way to give up worldly life.

\section{Kenosis}

Kenosis is a term often used in Christianity in connection with the total or absolute emptying of Jesus Christ in the task of saving humankind. Paul specifically wrote the

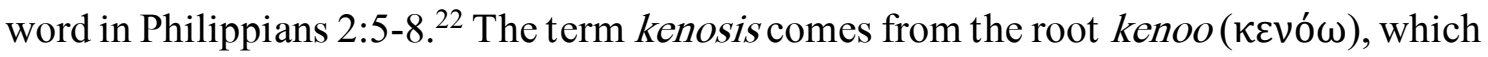
means to make it not to contain or to empty. The word kenoo also actually has the meaning to destroy. Another definition is rendering void or invalid (causing empty or invalid). So, kenosis means crushed or crushed to become empty. ${ }^{23}$

The concept of kenosis is not always used for preaching purposes in the church. The concept of kenosis is often associated with various science families because it is considered the values contained in it able to provide solutions to the problems faced. For example, Ramirez attributes it to leadership, where a fundamental relationship for moral leadership is kenosis or self-emptying sacrifice, particularly with transformational and authentic leadership. ${ }^{24}$

\section{Self-Emptying}

This concept of self-emptying in kenosis comes from what the Lord Jesus did, where He who is God Himself takes the form of a human being by emptying all the attributes of His divinity.

In 2 Corinthians 8:9, it says, "... That he, because of you, is poor, even though he is rich, that you may become rich because of his poverty." Even if $\mathrm{He}$ is rich, he has power and glory as God the Son, but being poor means giving up all his power and glory.

21 H. Muhtar Solihin.

22 Erastus Sabdono, Kristologi (Jakarta: Rehobot Literature, 2016), 50.

23 Erastus Sabdono, 53.

24 Andrea R. Ramirez, “The Impact of Kenosis on the Transformational Authentic Leader," in True Leadership (Palgrave Macmillan, Cham, 2020), 119-135, https://link.springer.com/chapter/10.1007/978-3-030-46660-2_8, accessed 14 October 2021. 
Although the Lord Jesus still had the opportunity to use power as God, He still acted as a Person who emptied himself and let himself be equated with man in all things. In His circumstances as a human being, He did not use at all His power and power as God as written in Philippians 2:5-8:

"Let this mind be in you, which was also in Christ Jesus: Who, being in the form of God, thought it not robbery to be equal with God: But made himself of no reputation, and took upon him the form of a servant, and was made in the likeness of men: And being found in fashion as a man, he humbled himself, and became obedient unto death, even the death of the cross. ${ }^{25}$

He became a man who had to rely entirely on the Father in Heaven by emptying himself. He prayed all night before choosing his disciples (Lk. 6:12-13). ${ }^{26}$ When He had to face the great suffering of the cross, He prayed in the garden of Gethsemane to invoke the strength of the Father in Heaven. Even in a statement, He referred to the Father as His God (Mark 15:34). He indeed became a man with all his limitations.

This self-emptying by the Lord Jesus becomes a pattern for humans who want to empty themselves of all the world's desires. One's self-emptying must make oneself utterly dependent on God the Creator. Dependence is not passive without doing any action or activity but instead acting according to God's will.

Concerning the life difficulties humans must face in pandemic situations (WFH or SFH), one's dependence on God should make the problem faced not an obstacle but a means to exercise our trust in His provider. The loneliness that plagues should be overcome by communicating with Him in prayer and surrendering life. Of course, this will eventually make someone strong. The interests that exist in him are no longer personal interests but the interests of the kingdom of God.

\section{Holy Life}

Chastity is often viewed as an existence that particular people who have different living areas than humans, in general, can only be possessed. Those who are considered to attain holiness are the ones who must leave a natural life in this world, isolating themselves in places unreachable by the busyness and noise of life. Purity is considered unattainable by those who live reasonably amid society with various life activities. So that to live a holy life, one must live in a monastery or a kind of hermitage. But in another opinion, Sabdono said that holiness amid the temptation of sin is accompanied by respect for God and a heart that truly loves Him. ${ }^{27}$

A holy life is not only characterized by living avoiding acts that violate common morals such as committing murder, adultery, robbery, and the like, but also actions that

25 Rick Meyers, "E-Sword X," 2021.

26 Rick Meyers, "E-Sword X," 2021.

27 Erastus Sabdono, “Mencapai Kesucian” (Jakarta: Rehobot Literature, 2019), 25. 
are incompatible with God's thoughts and feelings. Sins that are disguised in the heart can occur at any time without external stimulation. This is why even holy life is inward.

Holy life means also living to let go of everything, where there is a willingness not to be bound by the world amid the possibilities of owning and enjoying it. If a person does not have the potential and opportunity to reach the world and then leave it, it does not mean he has released it proportionally. The Apostle Paul could have all things, but he let them go and considered them trash, as he wrote in a letter to the Philippians (Php. $3: 7-9)$ :

"But what things were gain to me, those I counted loss for Christ. Yea doubtless, and I count all things but loss for the excellency of the knowledge of Christ Jesus my Lord: for whom I have suffered the loss of all things, and do count them but dung, that I may win Christ, and be found in him, not having my righteousness, which is of the law, but that which is through the faith of Christ, the righteousness which is of God by faith:"28

One can be fasting tough if one is in a place with water and food but does not enjoy it. One cannot be tough fasting when in a wilderness with no water and no food. One's holiness is tested amid the possibility and opportunity of sinning but still chooses not to violate God's will.

Holiness can only be possessed by struggle. The sanctity of life cannot be owned by believers by itself or automatically. How high a person reaches depends not only on the grace God gives but also depends largely on one's struggle. That is why the Lord Jesus declared that to enter the Kingdom of Heaven must fight (Lk 13:24). ${ }^{29}$ On the other hand, the Lord Jesus states that many are called little to be chosen (Mathew. 22:14). ${ }^{30}$ Of course, this choice is also based on a person's response.

In the face of the pressures and difficulties of life, one's inner attitude is challenged to remain in the proper condition (holy). Is amid fatigue online activities, speeches that come out of the mouth are dominated by complaints or thanksgiving? A study states that gratitude has a significant correlation with a person's quality of life, meaning that the more grateful he is, the quality of life increases. This also happens to those who experience psychosomatics due to stress. ${ }^{31}$

\section{Focus on Eternity}

If in Sufism there is a value of giving up worldly life, then in kenosis, that value is represented by a focus on eternal life. Eternity does not always speak of Heaven, but

28 Meyers, Rick. "E-Sword X," 2021.

29 Meyers, Rick. "E-Sword X," 2021.

30 Meyers, Rick. "E-Sword X," 2021.

31 Ila Nurlaila Hidayat and Witrin Gamayanti, "Dengki, Bersyukur Dan Kualitas Hidup Orang Yang Mengalami Psikosomatik,” Psympathic: Jurnal Ilmiah Psikologi 7, no. 1 (July 1, 2020): 79-92, https://journal.uinsgd.ac.id/index.php/psy/article/view/6027. 
also hell. A person who empties himself against the world's values will direct himself to the things of Heaven.

In principle, living on this earth prepares life for eternity. A person's eternal state is determined by how he fills the day of his life. The mind of a person who thinks of eternity will appear from the behavior of his life. Therefore, one's area of thinking has an essential role in this.

Changing one's mindset is not easy, but it takes time and hard work. God does not conjure a person's mindset in an instant so that he can have a new perspective. The renewal of the mind here is the same as the continuous renewal of understanding; continuously. This renewal of the mind is not a momentary momentum or event but a process that goes on. The word of mind in Romans 12:2 (Do not be like this world, but be transformed by the renewal of your mind, so that you may discern what is God's will: what is good, pleasing to God and perfect.) ${ }^{32}$ Nous is related to consciousness (consciousness) to the truth that builds an understanding of the true meaning of life. The renewal of the mind will open consciousness, give insight, and give birth to divine perceptions.

Sabdono said that changing one's mindset is a continuous process resulting from hard work. This change resulted in a shift in life's direction, more than just a moral change. This change involves the pattern of thinking and all its philosophies, which also means a difference in the attitude of the heart of the mind's perspective. This change in thinking patterns is parallel to repentance, or in other words, repentance is a change in thinking patterns. ${ }^{33}$

Repentance is a new moral change and a changed direction of life. The direction of life that was oriented or focused on worldly things (materials) moved to the Kingdom of Heaven (things). The Greek word for repentance is metanoeo ( $\mu \varepsilon \tau \alpha \nu o \varepsilon ́ \omega)$, which means a change of mind. The transformation that occurs in a person opens his mind and consciousness so that he can appreciate where he came from and where he went, as written in John 3:8-11:

"The wind bloweth where it listeth, and thou hearest the sound thereof, but canst not tell whence it comesth, and whither it goeth: so is every one that is born of the Spirit. Nicodemus answered and said unto him, How can these things be? Jesus answered and said unto him, Art thou a master of Israel, and knowest not these things? Verily, I say unto thee; We speak that we do know, and testify that we have seen, and ye receive not our witness." 34

Change in mindset (transformation) is a change that takes place continuously or continuously. Transformation is a process of changing the behavior of a person and a

\footnotetext{
32 Meyers, "E-Sword X."

33 Erastus Sabdono, Transformasi Pikiran - Pembaharuan Pikiran Dalam Hidup Orang Percaya (Rehobot Literature, 2019), 63.

34 Meyers, "E-Sword X."
} 
community. A momentum or event that occurs in a moment. The transformation process can be described as a long line, not a dot. Transformation is not momentum but an ongoing process in someone's life. Transformation must come to perfection like the Father or similar to Jesus.

\section{E. Conclusion}

A person's tendency to get tired or bored with online activities is usually channeled by looking for entertainment that can satisfy his flesh (eyes and ears). They seek pleasures whose value is only momentarily able to release their fatigue so that when fatigue comes back, the repetition of the same thing often happens. The cycle of boredom and fatigue stops at the fulfillment of biological and emotional satisfaction but is pseudo. Some values in the concepts of Sufism and kenosis, such as self-emptying emotional control, provide different solutions. The values in these two concepts direct one's gaze to immortality by letting go of worldly desires and living holy lives.

A holy life is characterized not only by living avoiding acts that violate common morals such as committing murder, adultery, robbery, and the like, but also actions that are incompatible with God's thoughts and feelings. Sin disguised in the heart can occur at any time without external stimulation. This is why even the holy life is inside. In the face of life's stresses and difficulties, one's inner attitude is challenged to remain in the right (sacred) condition. Regarding the life difficulties humans must face in a pandemic situation (WFH or SFH), one's dependence on God should make the problem at hand not an obstacle but a means to exercise our trust in His provider. The loneliness that plagues must be overcome by communicating with Him in prayer and surrendering life. Selfishness, greed, and love of the world must be suppressed and replaced with a $z u h u \bar{d}$ attitude characterized by sharing and loving each other. Refraining from seeking a spectacle that can satisfy the eyes and fantasizing amid fatigue using zoom is another way to let go of worldly life. As a social creature (zoon politicon), although limited by online meetings (zoom) in this pandemic era, human values must still be put forward to reflect one's spiritual journey with the Divine. All these existing values are fences that protect a person from being caught up in a sin that eventually perishes. These values can also be the basis for a person to survive all the challenges in life, especially in the fatigue of online activities. 


\section{Bibliography}

Central, Proquest. "The Connection between Spirituality and Policing," 2010. Accessed 14 October 2021. https://www.spiritrestoration.org/life/connection-betweenspirituality-resilience/.

CNET. "Zoom Punya Game Yang Bisa Dimainkan Sambil Meeting." Tekno.Kompas. Last modified 2021. Accessed October 13, 2021. https://tekno.kompas.com/read/2021/07/25/15410067/zoom-punya-game-yangbisa-dimainkan-sambil-meeting.

Febriananingsih, Nunuk. "Jurnal RechtsVinding." Keterbukaan Informasi Publik Dalam Pemerintaan Terbuka Menuju Tata Pemerintahan Yang Baik 1, no. April (2012): 135-156. Accessed October 13, 2021. https://rechtsvinding.bphn.go.id/view/view_online.php?id=318.

Gitosaroso, Moh. “Kecerdasan Emosi (Emotional Intelligence Dalam Tasawuf).” Jurnal Khatulistiwa - Journal Of Islamic Studies 2, no. 2 (2012): 193. https://jurnaliainpontianak.or.id/index.php/khatulistiwa/article/view/206/165.

H. Muhtar Solihin. "Memaknai Zuhud Kontekstual Di Masa Covid-19." UIN Sunan Gunung Djati Bandung. Last modified 2020. Accessed October 20, 2021. https://uinsgd.ac.id/memaknai-zuhud-kontekstual-di-masa-covid-19/.

Hamali, Syaiful. "ASKETISME DALAM ISLAM PERSPEKTIF PSIKOLOGI AGAMA." Al-Adyan: Jurnal Studi Lintas Agama 10, no. 2 (2015): 202-215. Accessed October 20, 2021. http://ejournal.radenintan.ac.id/index.php/alAdyan/article/view/1429.

Herrman, Helen, Donna E Stewart, Natalia Diaz-Granados, Elena L Berger, Beth Jackson, and Tracy Yuen. "What Is Resilience?" Canadian Journal of Psychiatry. SAGE PublicationsSage CA: Los Angeles, CA, May 1, 2011. Accessed 14 October 2021. https://journals.sagepub.com/doi/abs/10.1177/070674371105600504.

Hidayat, Ila Nurlaila, and Witrin Gamayanti. "Dengki, Bersyukur Dan Kualitas Hidup Orang Yang Mengalami Psikosomatik." Psympathic : Jurnal Ilmiah Psikologi 7, $\begin{array}{lllll}\text { no. } & 1 & \text { (July } & \text { 2020): }\end{array}$ https://journal.uinsgd.ac.id/index.php/psy/article/view/6027.

INDOZONE.ID. "5 Aplikasi Meeting Online Dan Video Conference Jarak Jauh Terbaik." INDOZONE.ID. Last modified 2020. Accessed October 13, 2021. https://www.indozone.id/tech/pQsoXr/5-aplikasi-meeting-online-dan-videoconference-jarak-jauh-terbaik/read-all.

Keye, Michelle D., and Aileen M. Pidgeon. "Investigation of the Relationship between Resilience, Mindfulness, and Academic Self-Efficacy." Open Journal of Social $\begin{array}{lllll}\text { Sciences } & 01, & \text { no. } & 06 & \text { (2013): }\end{array}$ http://www.scirp.org/journal/doi.aspx?DOI=10.4236/jss.2013.16001. 
Komunitas Traveler Kompasiana. "Begini Sejarah Zoom Komunitas Traveler Kompasiana Oleh Koteka Kompasiana - Kompasiana.Com." Last modified February 23, 2021. Accessed October 13, 2021. https://video.kompasiana.com/kotekasiana/6034bbe301be08657d72b065/beginisejarah-zoom-komunitas-traveler-kompasiana?page $=4$.

Kuntardi, Dina Vebiola Saraswati. "Zoom Fatigue Dan Keberfungsian Sosial Di Kalangan Mahasiswa.” Jurnal Publisitas 7, no. 2 (April 27, 2021): 72-79.

Lori. "7 Games Seru Ini Bisa Dimainin Di Zoom Bareng Komunitas Gerejamu Loh!" Jawaban. Last modified 2020. Accessed October 13, 2021. https://www.jawaban.com/read/article/id/2020/07/12/15/200710162308/7_games _seru_ini_bisa_dimainin_di_zoom_bareng_komunitas_gerejamu_loh.

Malang, BEM Fakultas Pendidikan Psikologi Universitas Negeri. "Zoom Fatigue, Apakah Berpengaruh Terhadap Kesehatan Mental?" [PSYCHOFACT Vol.1]. Last modified 2021. Accessed October 12, 2021. http://bem.fppsi.um.ac.id/index.php/2021/06/20/psychofact-vol-1-zoom-fatigueapakah-berpengaruh-terhadap-kesehatan-mental/.

Meyers, Rick. "E-Sword X," 2021.

Mobilesyrup. "Zoom Akan Punya Penerjemah Bahasa 'Real Time." Tekno.Kompas. Last modified 2021. Accessed October 13, 2021. https://tekno.kompas.com/read/2021/07/04/08050037/zoom-akan-punyapenerjemah-bahasa-real-time-.

Peper, Erik, Vietta Wilson, Marc Martin, Erik Rosegard, and Richard Harvey. "Avoid Zoom Fatigue, Be Present and Learn." NeuroRegulation 8, no. 1 (March 29, 2021): $47-56$.

Pustikasari, Atikah, and Lia Fitriyanti. "Stress Dan Zoom Fatigue Pada Mahasiswa Selama Pembelajaran Daring Di Masa Pandemi Covid-19." Jurnal Ilmiah Kesehatan 13, no. 1 (March 30, 2021): 25-37. Accessed October 12, 2021. http://journal.thamrin.ac.id/index.php/jikmht/article/view/467.

Ramirez, Andrea R. "The Impact of Kenosis on the Transformational Authentic Leader." In True Leadership, 119-135. Palgrave Macmillan, Cham, 2020. Accessed 14 October 2021. https://link.springer.com/chapter/10.1007/978-3-030-46660-2_8.

Reivich, K \& Shatte, A. The Resilience Factor; 7 Essential Skills For Overcoming Life's Inevitable Obstacle. New York: Broadway Books, 2002.

Sabdono, Erastus. Kristologi. Jakarta: Rehobot Literature, 2016.

."Mencapai Kesucian.” Jakarta: Rehobot Literature, 2019.

Transformasi Pikiran - Pembaharuan Pikiran Dalam Hidup Orang Percaya. Rehobot Literature, 2019. 
Gitosaroso, Moh. "Kecerdasan Emosi (Emotional Intelligence Dalam Tasawuf)," Jurnal Khatulistiwa - Journal Of Islamic Studies 2, no. 2 (2012): 193, https://jurnaliainpontianak.or.id/index.php/khatulistiwa/article/view/206/165.

Segal, Jeanne. Raising Your Emotional Intelligence, Terj. Ali Nilandari Mendayagunakan, Melejitkan Kepekaan Emosional; Cara Baru-Praktis Untuk Potensi Insting Dan Kekuatan Emosi Anda. Cet. I. Bandung,: Kaifa, 2000.

Zainuddin, H M. “Sufisme Di Era Global.” UIN Maulana Malik Ibrahim Malang, 2015. Accessed October 10, 2021. https://www.uin-malang.ac.id/r/131101/sufisme-diera-global.html.

Zaluchu, Sonny Eli. "Strategi Penelitian Kualitatif Dan Kuantitatif Di Dalam Penelitian Agama." Evangelikal: Jurnal Teologi Injili dan Pembinaan Warga Jemaat 4, no. 1 $\begin{array}{lll}\text { (January } 31, & 2020):\end{array}$ https://journal.sttsimpson.ac.id/index.php/EJTI/article/view/167. 